\title{
Peripheral neuropathy during longterm high-dose amiodarone therapy
}

\author{
AG FRASER, INF McQUEEN, AH WATT, MR STEPHENS \\ From the Departments of Cardiology and Neurology, University Hospital of Wales, Cardiff, UK
}

SUMMARY Three patients developed peripheral neuropathy after taking amiodarone for more than 18 months. All had high serum concentrations of amiodarone and its desethyl metabolite; in one patient concentrations in a sural nerve biopsy were 80 times higher than in serum. Peripheral neuropathy is a complication of large doses of amiodarone taken over long periods.

The antiarrhythmic drug amiodarone was first reported as a cause of peripheral neuropathy in $1974 . .^{2}$ Subsequent authors have confirmed this association $^{3-11}$ but they have not explained why particular patients develop this adverse effect. We report three patients who developed peripheral neuropathy while taking amiodarone. Drug concentrations were measured in serum and in one patient also in a peripheral nerve biopsy, and recovery was documented after withdrawal of amiodarone. Similar details have not been reported before. With information from previous reports, some factors can be identified which may be important in the genesis of amiodarone neuropathy.

\section{Case reports}

\section{Patient 1}

A 65-year-old lady presented in 1981 with paroxysmal atrial arrhythmias. She was given amiodarone $200 \mathrm{mg}$ tid for 1 week, and thereafter $200 \mathrm{mg}$ bd. Her arrhythmias were abolished but in September 1983 she reported progressive weakness of her legs over 6 months. She had become too weak to walk even with support, and had paraesthesiae in her arms and legs, numbness in her legs below the knees, and a tremor. On examination she had a distal symmetrical sensorimotor neuropathy with areflexia. Sensory nerve conduction studies (table) demonstrated

Address for reprint requests: Dr AG Fraser, Department of Cardiology, University of Wales College of Medicine, Heath Park, Cardiff CF $44 \mathrm{XN}$, UK.

Received 13 March 1984 and in final revised form 14 October 1984.

Accepted 29 October 1984 reduced amplitude sensory nerve action potentials in the upper limbs, and absent sural nerve action potentials. Motor studies showed considerable slowing of maximum conduction velocity with marked dispersion in the median and ulnar nerves, while velocity could not be measured in the common peroneal nerve because extensor digitorum brevis was denervated. The results were compared with reference values quoted by $\mathrm{Ma}$ and Liveson. ${ }^{12}$ Two weeks after the amiodarone was stopped sural nerve biopsy was performed. The histological appearances were similar to previous reports of amiodarone neuropathy. ${ }^{56810}$ Biochemical analysis by high performance liquid chromatography ${ }^{1314}$ gave an amiodarone concentration in the nerve of $187 \mathrm{mg} / \mathrm{kg}$ wet weight, and a desethylamiodarone concentration of $203 \mathrm{mg} / \mathrm{kg}$ wet weight. At the same time serum concentrations were 2.3 and $2.6 \mathrm{mg} / \mathrm{l}$ respectively. Her symptoms started to improve soon after amiodarone was stopped, but no objective improvement was detected until 10 weeks later. After 4 months her paraesthesiae were greatly reduced in severity and muscle power had improved so that she could walk unaided. Knee jerks had returned but ankle jerks were still absent. After 9 months she had no sensory symptoms and muscle power was almost normal. Tests of motor nerve conduction confirmed a significant improvement.

\section{Patient 2}

This man with coronary artery disease presented in 1980 aged 73 yr with syncope caused by paroxysmal ventricular tachycardia. His arrhythmias were successfully controlled by amiodarone $200 \mathrm{mg}$ daily but recurred after one year He then took $600 \mathrm{mg}$ daily for more than 2 years, followed by $400 \mathrm{mg}$ daily for 2 months before the drug was discontinued. One year after starting amiodarone he reported a tremor, and 6 months later he reported unsteadiness when walking. Thereafter he developed progressive weakness of his arms and legs, dysaesthesiae in his hands and numbness in his legs. Treatment was continued until November 1983, 
Peripheral neuropathy during longterm high dose amiodarone therapy

Table Details of amiodarone treatment, and results of nerve conduction tests.

\begin{tabular}{|c|c|c|c|c|c|c|c|c|c|c|c|c|c|c|c|c|}
\hline \multirow[t]{4}{*}{ Patient } & \multirow{4}{*}{$\begin{array}{l}\text { Duration } \\
\text { of } \\
\text { treatment } \\
m\end{array}$} & \multirow{4}{*}{$\begin{array}{l}\text { Total } \\
\text { dose } \\
\text { received } \\
g\end{array}$} & \multirow{4}{*}{$\begin{array}{l}\text { Date } \\
\text { of } \\
\text { study }\end{array}$} & \multicolumn{2}{|c|}{ Serum concentrations } & \multicolumn{5}{|c|}{ Sensory nerve action potentials } & \multicolumn{6}{|c|}{ Motor Studies } \\
\hline & & & & \multirow{3}{*}{$\begin{array}{l}\text { Amiodarone } \\
\mathrm{mg} / \mathrm{l}\end{array}$} & \multirow{3}{*}{$\begin{array}{l}\text { Desethyl } \\
\text { amiodarone } \\
\text { mg/l }\end{array}$} & \multicolumn{4}{|c|}{ Upper limb } & \multirow{3}{*}{$\begin{array}{l}\text { Lower limb } \\
\text { Sural nerve } \\
A \\
\mu V\end{array}$} & \multirow{2}{*}{\multicolumn{2}{|c|}{$\begin{array}{l}\text { Median } \\
\text {-nerve }\end{array}$}} & \multirow{2}{*}{\multicolumn{2}{|c|}{$\begin{array}{l}\text { Ulnar } \\
\text { nerve }\end{array}$}} & \multirow{2}{*}{\multicolumn{2}{|c|}{$\begin{array}{l}\text { Common } \\
\text { peroneal nerve }\end{array}$}} \\
\hline & & & & & & \multirow{2}{*}{$\begin{array}{l}\mathrm{D} 2 \\
\mathrm{TO} \\
\mathrm{ms}\end{array}$} & \multirow[b]{2}{*}{$\begin{array}{l}A \\
\mu V\end{array}$} & \multirow{2}{*}{$\begin{array}{l}D 5 \\
T O \\
m s\end{array}$} & \multirow[b]{2}{*}{$\begin{array}{l}A \\
\mu V\end{array}$} & & & & & & & \\
\hline & & & & & & & & & & & \multirow{2}{*}{$\begin{array}{l}\begin{array}{l}D L \\
m s\end{array} \\
6 \cdot 0\end{array}$} & $\begin{array}{l}C V \\
M s^{-1}\end{array}$ & $\begin{array}{l}D L \\
m s\end{array}$ & $\begin{array}{l}C V \\
M s^{-1}\end{array}$ & $\begin{array}{l}D L \\
m s\end{array}$ & $\begin{array}{l}C V \\
M s^{-1}\end{array}$ \\
\hline 1 & 26 & 321 & 28. 9.83 & $3 \cdot 1$ & $3 \cdot 2$ & $3 \cdot 7$ & $3 \cdot 5$ & $3 \cdot 7$ & 0.5 & $\mathbf{0}$ & & 32 & $4 \cdot 4$ & 34 & 0 & 0 \\
\hline & & & 2.11 .83 & $\overline{20}$ & - & $3 \cdot 3$ & $2 \cdot 5$ & 0 & 0 & 0 & $\bar{\varepsilon}$ & - & - & - & - & - \\
\hline & & & 14.12 .83 & $2 \cdot 2$ & $1 \cdot 4$ & $3 \cdot 2$ & $4 \cdot 7$ & $2 \cdot 8$ & $1 \cdot 7$ & 0 & $5 \cdot 9$ & 34 & $4 \cdot 4$ & 41 & 0 & 0 \\
\hline 2 & 42 & 505 & $\begin{array}{r}20.0 .84 \\
25.1083\end{array}$ & $\begin{array}{l}0.5 \\
1.8\end{array}$ & 0.8 & 2.8 & $6 \cdot 5$ & $\begin{array}{l}2.9 \\
2.8\end{array}$ & $1 \cdot 0$ & $\bar{n}$ & $4 \cdot 6$ & 45 & $3 \cdot 5$ & 48 & $9 \cdot 2$ & 24 \\
\hline & & & 24.2 .84 & - & $\underline{3.4}$ & $\begin{array}{l}2.0 \\
2.9\end{array}$ & $\begin{array}{l}3.0 \\
2.0\end{array}$ & $2 \cdot 8$ & $2 \cdot 0$ & $\begin{array}{l}0 \\
0\end{array}$ & $\begin{array}{l}5 \cdot 9 \\
4 \cdot 8\end{array}$ & $\begin{array}{l}48 \\
45\end{array}$ & $\begin{array}{l}5 \cdot 7 \\
5 \cdot 3\end{array}$ & $\begin{array}{l}39 \\
40\end{array}$ & $\begin{array}{r}11.2 \\
8.5\end{array}$ & $\begin{array}{l}28 \\
34\end{array}$ \\
\hline 3 & 32 & 494 & 16. 3.83 & $2 \cdot 3$ & $2 \cdot 3$ & $2 \cdot 6$ & $4 \cdot 8$ & $2 \cdot 3$ & $3 \cdot 6$ & $3 \cdot 6$ & $4 \cdot 0$ & 47 & $3 \cdot 2$ & 49 & $3 \cdot 8$ & 46 \\
\hline & & & 11. 1.84 & 0.3 & 0.9 & $2 \cdot 2$ & $9 \cdot 0$ & $2 \cdot 2$ & $5 \cdot 0$ & $7 \cdot 0$ & 3.5 & 51 & $3 \cdot \overline{2}$ & 50 & $4 \cdot 0$ & 49 \\
\hline
\end{tabular}

Abbreviations: TO Latency to negative take-off of action potential

$$
\begin{aligned}
& \text { A Amplitude of action potential } \\
& \text { DL Distal latency } \\
& \text { CV Conduction velocity } \\
& \text { O No activity recorded } \\
& \text { - Investigation not performed }
\end{aligned}
$$

when he was unable to stand properly and could walk slowly only with help. He had muscle wasting, severe weakness in his arms and legs, areflexia and sensory loss. Nerve conduction studies confirmed a severe mixed sensory and motor peripheral neuropathy (table). Three months after stopping amiodarone the symptoms had improved considerably. He felt that he could walk normally, but there had been no significant improvement in the results of nerve conduction tests. Motor studies demonstrated improved terminal latencies but no action potentials could be detected from the sural nerve.

\section{Patient 3}

A 50-year-old man with hypertensive heart disease was prescribed amiodarone in August 1980 for ventricular tachycardia. He took either $400 \mathrm{mg}$ or $600 \mathrm{mg}$ of amiodarone daily for almost 3 years. In March 1983 he complained of unsteadiness, tremor, paraesthesiae and numbness. He had burned his hand because of poor temperature sensation, but he had no muscle weakness and no other demonstrable sensory loss. Nerve conduction tests showed low amplitude sensory nerve action potentials, and reduced nerve conduction velocities (table). Amiodarone was stopped in July 1983 when the paraesthesiae became very troublesome. Six months later his sensory symptoms had almost completely resolved, and sensory nerve conduction showed a significant improvement.

\section{Discussion}

Two patients developed a severe sensorimotor neuropathy while taking amiodarone, and the third severe sensory symptoms with objective evidence of neuropathy. Other causes were excluded, and no patient was taking another drug reported to cause neuropathy. Nerve conduction studies suggested a chronic peripheral neuropathy with segmental demyelination. Our patients developed symptoms after taking amiodarone for 18,19 and 30 months, compared with 24 months on average in the 20 patients previously reported. ${ }^{1-11}$ Their mean age was the same as in other reports (65 years). The average maintenance dose of amiodarone was also similar; $533 \mathrm{mg} /$ day in our patients compared with $505 \mathrm{mg} /$ day in other series. ${ }^{1-11}$

Compared with a suggested therapeutic range for amiodarone of $1 \cdot 0-2.5 \mathrm{mg} / \mathrm{l}^{15}$ drug levels in our patients with neuropathy were high. The mean serum concentrations of amiodarone $(2.4 \mathrm{mg} / \mathrm{l})$ and desethylamiodarone $(3.0 \mathrm{mg} / \mathrm{l})$ were similar to two previous reports (amiodarone 2.4 and $5.0 \mathrm{mg} / \mathrm{l}$, and desesthylamiodarone 1.7 and $\left.4.0 \mathrm{mg} / \mathbf{l}^{1011}\right)$. Concentrations in the sural nerve biopsy were also high (about 80 times greater than in serum) and similar to the previous report of a forty fold increase in iodine content in an affected peripheral nerve. ${ }^{6}$ Drug concentrations in the sural nerve biopsy from our patient were higher than those found before in many other tissues at necropsy ${ }^{16}$ and in samples of sural nerve from two patients who died after taking $230 \mathrm{~g}$ of amiodarone over 19 months, and $240 \mathrm{~g}$ over 20 months (Drs D Holt and P Adams, personal communication). Neither had clinical evidence of neuropathy. Their sural nerve amiodarone concentrations were 70 and $43 \mathrm{mg} / \mathrm{kg}$ wet weight compared with $187 \mathrm{mg} / \mathrm{kg}$ in our patient, and the desethylamiodarone concentrations 69 and $116 \mathrm{mg} / \mathrm{kg}$ compared with $203 \mathrm{mg} / \mathrm{kg}$. High serum concentrations of amiodarone and its metabolite are associated with peripheral neuropathy. Related high tissue concentrations may be the material factor. Although patients have developed neuropathy while taking a standard dose such as $200 \mathrm{mg} /$ day $^{4} 7^{10}$ they may nevertheless have had high serum and tissue concentrations. Amiodarone is variably absorbed and other authors have not related dosage to body 
weight or measured drug levels.

The mechanism of amiodarone neuropathy is unclear and may be non-specific. The desethyl metabolite is present in high concentrations in lysosomes especially in tissues rich in macrophages, ${ }^{16}$ and variable density inclusion bodies thought to be of lysosomal origin have been observed in the cytoplasm of Schwann cells in electron micrographs of affected nerves. ${ }^{568}$ These findings also suggest that the accumulation of high concentrations of amiodarone and its metabolite in peripheral nerves may produce neuropathy. Very similar microscopic appearances occur in the neuropathy induced by perhexilene maleate. ${ }^{17}$

Severe peripheral neuropathy may not improve if treatment is discontinued. One patient who took amiodarone for 3 years after the onset of neurological symptoms showed no improvement when he died 3 months after the drug was stopped. ${ }^{6}$ Others have improved very little within the first few months of stopping amiodarone,${ }^{58}$ but most patients reported previously have recovered slowly over 3-6 months. Occasionally recovery has been incomplete even after 5 years. ${ }^{4}$ The serial nerve conduction tests in our patients provide some objective confirmation of these reports, with no change apparent at 1-3 months but considerable improvement thereafter.

Our experience together with that in other published reports suggests that amiodarone neuropathy is usually an adverse effect of longterm treatment, associated with high drug concentrations. It may be more common in older patients, perhaps because of altered pharmacokinetics producing high tissue concentrations. Patients who take large doses of amiodarone for long periods should be monitored for the development of neuropathic symptoms or signs, because reduction of dose or withdrawal of treatment may be necessary to prevent significant morbidity.

We thank Drs LG Davies and K Evans for permission to report patients under their care, Dr $\mathrm{R}$ Weiser for his assistance, and Dr D Holt and Mr GCA Storey, Poisons Unit, Guy's Hospital, London, for performing the amiodarone assays.

\section{References}

' Lustman F, Monseu G. Amiodarone and neurological side effects. Lancet 1974; 1:568.
${ }^{2}$ Kaeser HE. Amiodaron-Neuropathie. Schweiz Med Wschr 1974; 104:606-8.

${ }^{3}$ Kaeser HE, Ulrich J, Wüthrich R. AmiodaronNeuropathie. Schweiz Rundschau Med (PRAXIS) 1976;65:1121-2.

${ }^{4}$ Fischer C, Bady B, Trillet M, Schott B. Deux cas de neuropathie périphérique à l'amiodarone. Nouv Press Méd 1977;6:3645-6.

${ }^{5}$ Dudognon P, Hauw JJ, De Baecque C, Derrida JP, Escourolle R, Nick J. Neuropathie au chlorhydrate d'amiodarone. Etude clinique et histopathologique d'une nouvelle lipidose médicamenteuse. Rev Neurol (Paris) 1979; 135:527-40.

- Meier C, Kauer B, Müller U, Ludin HP. Neuromyopathy during chronic amiodarone treatment. A case report. J Neurol 1979;220:231-9.

${ }^{7}$ Larre P, Cocquet M, Maupetit J. Neuropathie à l'amiodarone. Nouv Press Méd 1981;10:2750.

${ }^{8}$ Lemaire JF, Autret A, Biziere K, Romet-Lemone JL, Gray F. Amiodaron neuropathy: Further arguments for human drug-induced neurolipidosis. Eur. Neurol 1982;21:65-8.

${ }^{9}$ Martinez-Arizala A, Sobol SM, McCarty GE, Nichols BR, Rakita L. Amiodarone neuropathy. Neurol (NY) 1983;33:643-5.

${ }^{10}$ Pellissier JF, Pouget J, Cros D, De Victor B, Serratrice G, Toga M. Peripheral neuropathy induced by amiodarone chlorhydrate. A clinicopathological study. J Neurol Sci 1984;63:251-66.

"Lim PK, Trewby PN, Storey GCA, Holt DW. Neuropathy and fatal hepatitis in a patient receiving amiodarone. Br Med J 1984;288:1638-9.

${ }^{12}$ Ma DM, Liveson JA. Nerve Conduction Handbook. Philadelphia: FA Davis, 1983.

${ }^{13}$ Storey GCA, Holt DW, Holt P, Curry PV. Highperformance liquid chromatographic measurement of amiodarone and its desethyl metabolite: Methodology and preliminary observations. Ther Drug Monit $1982 ; 4: 385-8$.

${ }^{14}$ Storey GCA, Adams PC, Campbell RWF, Holt DW. High-performance liquid chromatographic measurement of amiodarone and desethylamiodarone in small tissue samples after enzymatic digestion. J Clin Pathol 1983;36: 785-9.

is Haffajee CI, Love JC, Canada AT, Lesko LJ, Asdourian G, Alpert JS. Clinical pharmacokinetics and efficacy of amiodarone for refractory tachyarrhythmias. Circulation 1983;67:1347-55:

${ }^{16}$ Holt DW, Adams PC, Campbell RWF, Morley AR, Callaghan J, Storey GCA. Amiodarone and its desethyl metabolite: tissue distribution and ultrastructural changes in amiodarone treated patients. $\mathrm{Br} J$ Clin Pharmacol 1984;17:195-6P.

17 Baumann N, Hauw JJ. Iatrogenic neurological diseases of the peripheral nervous system. Prog Clin Biol Res 1980;39:327-36. 